\title{
REVIEW
}

\section{PUBLIC HEALTH NURSE SERVICES FOR MATERNAL-CHILD IMMIGRANT HEALTHCARE: A LITERATURE REVIEW}

\author{
Tantut Susanto \\ Department of Family and Community Health Nursing, Faculty of Nursing, University of Jember, Jember, Indonesia
}

Received July 18, 2017; Accepted January 9, 2018. Copyright: This is an open access article distributed under the terms of the Creative Commons Attribution International License (CC BY). http://creativecommons.org/licenses/by/4.0/

\begin{abstract}
Aim: To examine the impact of the complexity of regulations and restrictive policies on the accessibility of healthcare services for immigrants, particularly maternal and child healthcare. Public health nurses can facilitate management of healthcare services for immigrants in the community by preventing mortality and morbidity among the immigrant population. This literature review was used to identify the challenges faced by public health nurses in providing maternal-child immigrant healthcare. Design: A literature review. Methods: Relevant healthcare databases including PubMed, CINAHL, Scopus, and Google Scholar were searched using the following combination of search terms: public health nurses, maternal care, child care, and immigrants. Results: Six articles were included in the review. Immigrants (undocumented immigrant families in particular) have limited access to public healthcare services, due to factors such as: socio-demographics; language barriers; cultural differences; the status of unregistered families; psychological distress; and problems with health insurance. Public health nurses deliver health education, maternal and postnatal check-ups, and vaccination through community and/or home-based service programs. The role of immigrant health volunteers is facilitated by the partnership between public health nurses and the immigrant population in providing comprehensive maternal and child healthcare in the community. Conclusion: There are barriers that currently impact on the development of public health nurses' provision of maternal and child healthcare services to immigrants. Strategies that can be implemented to improve public health nurse competencies in maternal and child healthcare of immigrants include bicultural or bilingual training, and cultural competencies in visit programs.
\end{abstract}

Keywords: child care, immigrant, maternal care, public health nurses.

\section{Introduction}

Globally, there were 232 million international migrants in 2013, with the largest numbers residing in Europe (72 million) and Asia (71 million) (United Nation, 2014a). In addition, in 2013, the United Nations estimated that there were 35 million international migrants worldwide under the age of 20, and 11 million between the ages of 15 and 19 years (United Nation, 2014b). The welfare of many people in immigrant communities is at serious risk in many regards, including their social, economic, and physical well-being (Kim et al., 2002), especially regarding maternal and child healthcare (MCHC) services (Gu, Lee, Ushijima, 2004). Given the continued immigration that leads to a diversity of the world's population, so that public health nurses (PHN) need skills to provide care and services that are culturally competent (Tveiten, Severinsson, 2004). PHNs can promote child and parent

Corresponding author: Tantut Susanto, Department of Family and Community Health Nursing, Faculty of Nursing, University of Jember, Jl. Kalimantan 37 Jember, Jawa Timur, Indonesia; email:tantut_s.psik@unej.ac.id development through a PHN home visit (Jack, Dicenso, Lohfeld, 2005) to prevent the risk of perinatal mortality and morbidity among migrant women and their children (Calain-Watanabe, Lee, 2012).

\section{Aim}

The aim of this literature review is threefold. Firstly, this paper aims to identify factors related to the problems of MCHC among immigrants. Secondly, it seeks to identify the variety of PHN services regarding MCHC among immigrants. Finally, it provides an overview of the improvement in the provision of MCHC by PHNs in immigrant populations. Thus, the aim of this literature review is to review publications that provide information on the provision of PHNs performing MCHC services for immigrant populations.

\section{Methods}

Design

A literature review design was used for this study. 


\section{Eligibility criteria}

The inclusion criteria for the literature review in this study were that articles: 1) were written in English; 2) were published before March 2015 ; 3) contained primary research; 4) examined immigrant healthcare services; and 5) examined the PHN services in MCHC. The exclusion criteria for articles were: 1) duplicated papers; 2) studies that diverged from the topic of interest; and 3) studies that were not specific to MCHC by PHNs in a community context. Each article identified was read in full and assessed for relevance to the review using the following inclusion criterion: the article should provide information about MCHC services by PHNs in community/public health settings.

\section{Sources}

A literature search was conducted from January to March 2017 using the following electronic databases: PubMed; CINAHL; Scopus; and Google Scholar search engine from 1996 to 2017.

\section{Search}

Keywords included: "public health nurses"; "maternal care"; "child care"; and "immigrant". Varieties of combination searches were completed using MESH terms. Only articles published
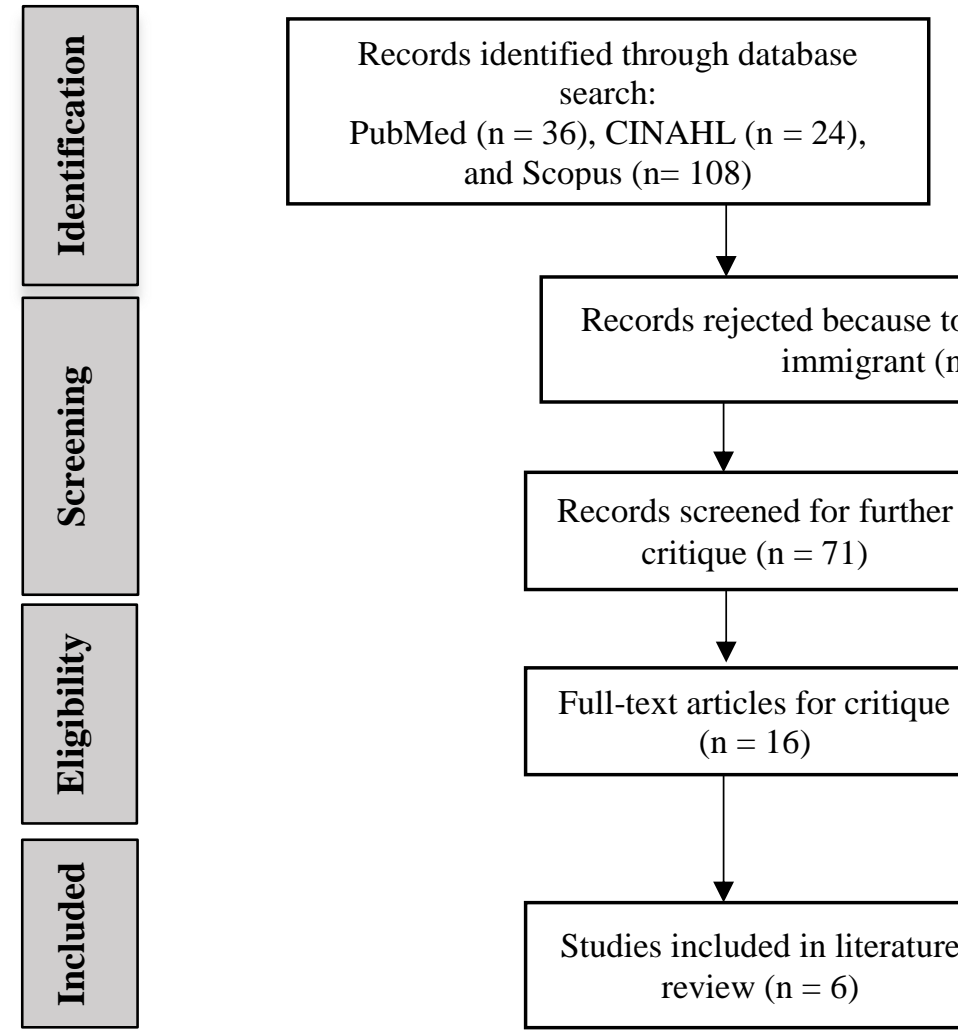

in English (a universal, well-accepted language) were included in the review. Protocols for a literature review were followed systematically, including: full citations, theoretical foundations, methodological features, and findings and conclusions (Polit, Beck, 2010). The searches produced a total of 1,017 articles.

\section{Study selection}

The review was conducted in four stages (Figure 1) using a PRISMA flow diagram. Firstly, from the initial search, 1,017 extracts were retrieved as follows: PubMed - 36; CINAHL - 24; Scopus - 108; and Google Scholar - 849. Secondly, abstracts were checked against the inclusion criteria. 936 articles based on the topic but which did not include services for immigrants were rejected. Thirdly, from the remaining 71 articles, we selected 16 for critique based on their full text. We removed five articles whose abstracts did not focus on PHNs, and five articles that were duplicates. Finally, we critically appraised the full texts of the six selected articles independently. The reference lists of the six articles were grouped (Table 1).
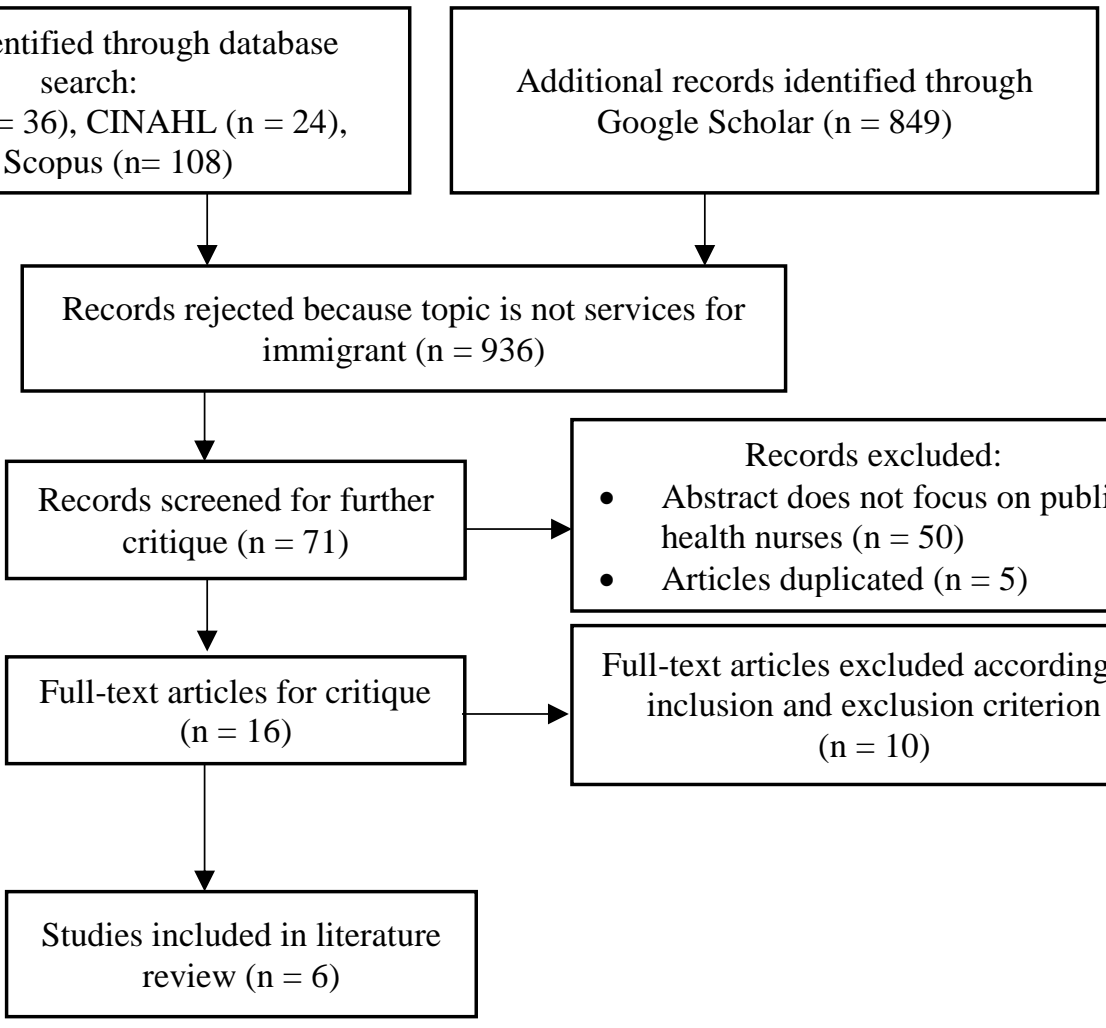

Records excluded:

- Abstract does not focus on public health nurses $(\mathrm{n}=50)$

- $\quad$ Articles duplicated $(\mathrm{n}=5)$

Full-text articles excluded according to inclusion and exclusion criterion

$$
(\mathrm{n}=10)
$$

Figure 1 Selection of studies (PRISMA flow chart) 


\section{Data analyses}

The process of selecting a study using the PRISMA diagram approach is shown in Figure 1. The authors analyzing the literature in this review focuses on PHN services for MCHC (Table 1).

\section{Results}

The review identified six articles that met the inclusion criteria. Most articles discussed the healthcare services for immigrants focusing on MCHC services (Table 1). Of these six articles, two were descriptive cross-sectional studies that identified the problems and related factors of MCHC services for immigrants. One article was a crosssectional survey regarding the problems and dilemmas of healthcare workers who provide healthcare services to immigrants. The third article was a quasi-experimental study with a quantitative and qualitative method approach to healthcare workers providing $\mathrm{MCHC}$ to immigrants.

The two articles by Gu, Lee, Ushijima (2004), and Calain-Watanabe, Lee (2012) describe how immigrants (especially undocumented immigrant families) have limited access to public healthcare services (PHC), related to factors such as: sociodemographics; language barriers; cultural differences; the status of unregistered families; psychological distress; and problems with health insurance. Meanwhile, three articles Gany, Thiel de Bocanegra (1996), Stevens, Lee, Sawada (2000), and Paris, Bronson (2006) examined MCHC programs for immigrants involving healthcare providers whereby PHNs delivered health education, maternal and postnatal check-ups, and vaccination through community and/or home-based services. In addition, the MCHC program facilitated the work of immigrant health volunteers by a partnership between PHNs and the immigrant population in providing comprehensive MCHC services in the community. The implementation of an MCHC program for immigrants has limitations and barriers relating to differences in cultural and linguistic background. Furthermore, the article by Ruiz-Casares et al. (2013), illustrating the problems and dilemmas among healthcare providers, identifies inequality of healthcare services as a human rights issue.

\section{Discussion}

The review of the literature outlined past and current provision of MCHC services by PHNs, including the type of care and the facilitators of, and barriers to, healthcare in relation to immigrants (in particular, mothers and their children). According to the literature review, immigrants have problems regarding access to MCHC services. Community and home-based MCHC programs are developed between PHNs and immigrants to provide comprehensive healthcare in community settings, although the programs have limitations and barriers relating to the cultural and linguistic backgrounds of immigrants. This situation impacts on the problems and dilemmas of healthcare workers in continuing to provide a program of services to immigrants.

Immigrants (undocumented immigrant families in particular) have limited access to public healthcare services (PHC). The situation of lacking health insurance is more common among immigrant children than non-immigrant children. Among those who are insured, immigrants fared worse in almost every access and utilization outcome (Guendelman et al., 2005). Health insurance is the main factor in access to healthcare for immigrants $(\mathrm{Ku}, 2007)$. Lack of health insurance among immigrants is related to the socio-demographic and unregistered status of families (Calain-Watanabe, Lee, 2012), which has an impact on psychological distress, and decreases the health status of immigrant families when the health status of immigrants is related to duration of residence (Frisbie, Cho, Hummer, 2001). These findings suggest that immigrants should receive health insurance to facilitate healthcare services as part of the human right to healthcare.

Based on this literature review, the PHNs developed MCHC with community and home-based programs among immigrants. The programs started with training programs among public health providers regarding maternal and child healthcare. The training program for health providers has been very successful in enhancing healthcare providers' sensitivity toward immigrant health issues, which improves knowledge and attitudes of participants (Gany, Thiel de Bocanegra, 1996). The MCHC program for immigrants has improved patient care in communities. Community and home-based intervention strategies (Paris, Bronson, 2006) have been used to deliver action programs through home visits, including health education, maternal and postnatal check-ups, and vaccinations. Thus, homevisit interventions should be designed to serve immigrant families, as the healthcare providers and mothers are closely connected to their communities, and can, therefore, work effectively with families with multiple risk factors related to immigrant issues.

Public healthcare empowers the immigrant population through the work of health volunteers connected to the community program for $\mathrm{MCHC}$ services for immigrants. The immigrants and 
Table 1 Publication of Public Health Nurses' services for Maternal Child Healthcare for Immigrants: 1996-2016

\begin{tabular}{|c|c|c|c|c|c|}
\hline $\begin{array}{l}\text { Author (s) } \\
\text { (Year) }\end{array}$ & $\begin{array}{l}\text { Purpose of } \\
\text { study }\end{array}$ & Design & Subjects & Measure & Main Finding \\
\hline $\begin{array}{l}\text { Gany, Thiel } \\
\text { de Bocanegra } \\
(1996)\end{array}$ & $\begin{array}{l}\text { This article } \\
\text { describes the } \\
\text { program } \\
\text { development, } \\
\text { implementation } \\
\text { and evaluation } \\
\text { of training for } \\
\text { maternity care } \\
\text { with family } \\
\text { planning centers } \\
\text { approach }\end{array}$ & $\begin{array}{l}\text { Quasi } \\
\text { experimental }\end{array}$ & $\begin{array}{l}\text { All levels of } \\
\text { staff of } \\
\text { maternity infant } \\
\text { care family } \\
\text { planning } \\
\text { centers, } \\
\text { facilitating a } \\
\text { team approach } \\
\text { to immigrant } \\
\text { health care }\end{array}$ & $\begin{array}{l}\text { Epidemiological and patient } \\
\text { management skills in providing } \\
\text { services to diverse ethnic } \\
\text { groups with a focus on skills } \\
\text { training, such as cross- } \\
\text { language, cross-cultural } \\
\text { interviews, and the use of } \\
\text { epidemiological principles in } \\
\text { diagnosis and treatment. The } \\
\text { program is organized into five } \\
\text { sessions, namely: cross-cultural } \\
\text { health issues interviews by } \\
\text { working together through } \\
\text { translators; epidemiological } \\
\text { problems; attitudes and } \\
\text { practices in maternal and child } \\
\text { health, family dynamics and } \\
\text { interactions; and sessions for } \\
\text { follow-up and program } \\
\text { evaluation. }\end{array}$ & $\begin{array}{l}\text { This training has been very } \\
\text { successful in increasing the } \\
\text { healthcare provider's } \\
\text { sensitivity to immigrant health } \\
\text { problems. Measurements } \\
\text { before and after the tests show } \\
\text { a statistically significant } \\
\text { increase in the knowledge and } \\
\text { attitudes of trainees and the } \\
\text { results of the research show } \\
\text { that the implementation of } \\
\text { patient care is greatly } \\
\text { improved. }\end{array}$ \\
\hline $\begin{array}{l}\text { Stevens, Lee, } \\
\text { Sawada } \\
(2000)\end{array}$ & $\begin{array}{l}\text { This article } \\
\text { reports on } \\
\text { undocumented } \\
\text { migrant } \\
\text { mothers' and } \\
\text { children's } \\
\text { access to public } \\
\text { health care }\end{array}$ & $\begin{array}{l}\text { Descriptive } \\
\text { evaluation } \\
\text { programme }\end{array}$ & $\begin{array}{l}\text { Migrant women, } \\
\text { welfare office } \\
\text { caseworkers, } \\
\text { public } \\
\text { health office } \\
\text { nurses, and } \\
\text { doctors and } \\
\text { nurses in public } \\
\text { and private } \\
\text { hospitals }\end{array}$ & $\begin{array}{l}\text { The investigators in this study } \\
\text { were members of SABAY, } \\
\text { experienced community } \\
\text { members working with } \\
\text { volunteer groups and NGOs, } \\
\text { Kotobuki Medical Consultation } \\
\text { Team (IryoA han), Kalabaw-no- } \\
\text { Kai, and SHARE (Healthcare } \\
\text { Services in Asia \& Africa). The } \\
\text { results were obtained through } \\
\text { field notes or observations and } \\
\text { case studies were taken from } \\
\text { the activity of the voulunteer } \\
\text { activity. }\end{array}$ & $\begin{array}{l}\text { This study focuses on the } \\
\text { question of discrimination } \\
\text { against foreigners, especially } \\
\text { undocumented migrants, } \\
\text { focusing on health services; } \\
\text { local activities carried out to } \\
\text { what extent. The results show } \\
\text { that there is a difference } \\
\text { between law and practice; how } \\
\text { foreigners have inadequate } \\
\text { access to public health care, } \\
\text { have poor knowledge about } \\
\text { Japanese health facilities and } \\
\text { services available, less frequent } \\
\text { postnatal checkups, low } \\
\text { vaccination rates, and high } \\
\text { medical risks. }\end{array}$ \\
\hline $\begin{array}{l}\text { Gu, Lee, } \\
\text { Ushijima } \\
(2004)\end{array}$ & $\begin{array}{l}\text { This study } \\
\text { explores the } \\
\text { medical and } \\
\text { healthcare needs } \\
\text { of Chinese } \\
\text { women students }\end{array}$ & $\begin{array}{l}\text { A cross- } \\
\text { sectional } \\
\text { survey with } \\
\text { mixed method } \\
\text { approach }\end{array}$ & $\begin{array}{l}\text { Chinese women } \\
\text { who study at the } \\
\text { University of } \\
\text { Tokyo (UT) }\end{array}$ & $\begin{array}{l}\text { Quantitative approaches } \\
\text { measure demographic data } \\
\text { (maternal age and length of stay } \\
\text { in Japan, age of children and } \\
\text { questions about vaccination), } \\
\text { how they obtain information, } \\
\text { contacted, and utilize medical } \\
\text { and health services, particularly } \\
\text { maternal and child health. } \\
\text { The qualitative approach is } \\
\text { measured through the following } \\
\text { questions: (1) What do you } \\
\text { think about health services in } \\
\text { hospitals or local health } \\
\text { services? What is mother's } \\
\text { expectation? (2) What worries } \\
\text { do you have about your children } \\
\text { (for mothers)? (3) What } \\
\text { additional comments from the } \\
\text { participants? }\end{array}$ & $\begin{array}{l}\text { There are several maternal } \\
\text { issues in maternal and child } \\
\text { health services, such as } \\
\text { language barriers, preference } \\
\text { for translators at hospitals or } \\
\text { health centers, and medical } \\
\text { guidebooks with information } \\
\text { on vaccinations in Chinese. } \\
\text { Participants revealed their lack } \\
\text { of knowledge about health and } \\
\text { medical systems in Japan, and } \\
\text { their difficulties being } \\
\text { separated from their children. } \\
\text { In addition, there is also a lack } \\
\text { of knowledge about the health } \\
\text { care system in Japan and other } \\
\text { unclear health care. }\end{array}$ \\
\hline
\end{tabular}




\begin{tabular}{|c|c|c|c|c|c|}
\hline $\begin{array}{l}\text { Author (s) } \\
\text { (Year) }\end{array}$ & $\begin{array}{l}\text { Purpose of } \\
\text { study }\end{array}$ & Design & Subjects & Measure & Main Finding \\
\hline $\begin{array}{l}\text { Paris, } \\
\text { Bronson } \\
(2006)\end{array}$ & $\begin{array}{l}\text { This research } \\
\text { explains how } \\
\text { the Moms } \\
\text { program for } \\
\text { immigrants } \\
\text { facilitated by } \\
\text { the } \\
\text { paraprofessional } \\
\text { model responds } \\
\text { to the needs of } \\
\text { new mothers of } \\
\text { refugees and } \\
\text { immigrants } \\
\text { from countries } \\
\text { in Central } \\
\text { America, South } \\
\text { America and } \\
\text { Africa }\end{array}$ & $\begin{array}{l}\text { Case study } \\
\text { and project } \\
\text { evaluation of } \\
\text { Visiting } \\
\text { Moms } \\
\text { program }\end{array}$ & $\begin{array}{l}\text { Obstetricians, } \\
\text { midwifes, } \\
\text { pediatricians, or } \\
\text { psychotherapists } \\
\text { from the MGH } \\
\text { Chelsea } \\
\text { HealthCare } \\
\text { Centre refer } \\
\text { pregnant } \\
\text { women and new } \\
\text { mothers to the } \\
\text { Visiting Moms } \\
\text { Program at the } \\
\text { highest risk and } \\
\text { in the greatest } \\
\text { need of home- } \\
\text { visiting services }\end{array}$ & $\begin{array}{l}\text { The study focused on } \\
\text { measuring participant } \\
\text { demographic data, parent-child } \\
\text { interactions, and additional } \\
\text { stressors on the family. The } \\
\text { intervention program consists } \\
\text { of: (1) What is the beginning } \\
\text { and development of the } \\
\text { relationship; (2) How to } \\
\text { develop a working alliance; (3) } \\
\text { How to expand relationships to } \\
\text { gain public support; and (4) } \\
\text { How to train and supervise the } \\
\text { program. }\end{array}$ & $\begin{array}{l}\text { This home visit program shows } \\
\text { how paraprofessionals as well } \\
\text { as mothers can be in close } \\
\text { contact with their communities } \\
\text { so that they can work } \\
\text { effectively with families with } \\
\text { various risk factors, including } \\
\text { trauma. Intensive training and } \\
\text { close supervision by a senior } \\
\text { doctor and program } \\
\text { administrator, resources from } \\
\text { well-coordinated public health } \\
\text { teams and outstanding health } \\
\text { centers, home visitors with } \\
\text { multilingual or bicultural } \\
\text { capabilities can provide } \\
\text { emotional support, client } \\
\text { advocacy in the service system } \\
\text { health, and education in } \\
\text { children. Development for low- } \\
\text { income and high-risk } \\
\text { immigrant/refugee families is } \\
\text { indispensable through this } \\
\text { home-visit program. }\end{array}$ \\
\hline $\begin{array}{l}\text { Calain- } \\
\text { Watanabe, } \\
\text { Lee } \\
(2012)\end{array}$ & $\begin{array}{l}\text { This article } \\
\text { discusses the } \\
\text { potential impact } \\
\text { of the new } \\
\text { Residency } \\
\text { Residency } \\
\text { System that will } \\
\text { be implemented } \\
\text { on } \\
\text { undocumented } \\
\text { migrant health } \\
\text { and their } \\
\text { children }\end{array}$ & $\begin{array}{l}\text { Descriptive } \\
\text { cross- } \\
\text { sectional } \\
\text { study }\end{array}$ & $\begin{array}{l}\text { Immigrants in } \\
\text { Japan }\end{array}$ & $\begin{array}{l}\text { The new Residency } \\
\text { Management System was } \\
\text { introduced in July } 2012 \text { to } \\
\text { accommodate the needs of } \\
\text { foreigners for the better. } \\
\text { Regulation of maternal and } \\
\text { child health services to access } \\
\text { health services under new } \\
\text { regulations on health insurance } \\
\text { for immigrants. }\end{array}$ & $\begin{array}{l}\text { Pregnant women and } \\
\text { undocumented newborns are at } \\
\text { increased risk of complications, } \\
\text { because many factors influence } \\
\text { and each factor interacts with } \\
\text { each other. The main problems } \\
\text { faced by undocumented } \\
\text { migrants are access to health } \\
\text { care, social isolation, financial } \\
\text { burden, and trans-generational } \\
\text { effects. }\end{array}$ \\
\hline $\begin{array}{l}\text { Ruiz-Casares } \\
\text { et al. } \\
(2013)\end{array}$ & $\begin{array}{l}\text { This study } \\
\text { describes the } \\
\text { value dilemmas } \\
\text { faced by health } \\
\text { care providers, } \\
\text { administrators, } \\
\text { and support } \\
\text { staff in the face } \\
\text { of mandates to } \\
\text { respect the } \\
\text { different human } \\
\text { rights } \\
\text { conventions and } \\
\text { ethical } \\
\text { obligations and } \\
\text { apply limited } \\
\text { access rules. }\end{array}$ & $\begin{array}{l}\text { The study was } \\
\text { conducted } \\
\text { through } \\
\text { surveys using } \\
\text { the Monkey } \\
\text { Survey } \\
\text { software and } \\
\text { posted for a } \\
\text { period of 2-3 } \\
\text { consecutive } \\
\text { weeks in } \\
\text { April-June } \\
\text { 2010 on each } \\
\text { agency } \\
\text { intranet. }\end{array}$ & $\begin{array}{l}\text { Doctors, } \\
\text { administrators, } \\
\text { and support } \\
\text { staff at the } \\
\text { hospital and } \\
\text { primary care } \\
\text { center are great } \\
\text { on multiethnic } \\
\text { cities are } \\
\text { involved in } \\
\text { online surveys } \\
\text { of attitudes } \\
\text { toward access to } \\
\text { health care. }\end{array}$ & $\begin{array}{l}\text { Questions on the online survey } \\
\text { consist of } 18 \text { multiple choice } \\
\text { questions and one open } \\
\text { question, which consists of: (1) } \\
\text { demographics, professional } \\
\text { jobs, and affiliations; (2) } \\
\text { exposures of diverse and } \\
\text { culturally undocumented } \\
\text { populations; (3) the perceived } \\
\text { magnitude and consequences of } \\
\text { access to health services; (4) } \\
\text { attitudes to rights (universal } \\
\text { access, limited access, no } \\
\text { access) to undocumented } \\
\text { migrant children and pregnant } \\
\text { women; and (5) support for the } \\
\text { most common reasons for } \\
\text { limiting and extending health } \\
\text { services including human } \\
\text { rights, and child development. }\end{array}$ & $\begin{array}{l}\text { Participants born abroad and } \\
\text { who are in primary care centers } \\
\text { perceive that access to services } \\
\text { obtained is very serious, } \\
\text { especially in support for access } \\
\text { or full of services, based on the } \\
\text { concept of human rights. } \\
\text { Doctors are more likely to } \\
\text { support wider or fuller access } \\
\text { to services than other health } \\
\text { care staff. Participants argue } \\
\text { that restrictions on access to } \\
\text { health services conflict with } \\
\text { basic human rights, especially } \\
\text { priorities on child } \\
\text { development. A wide gap } \\
\text { exists on the separation of } \\
\text { attitudes toward the right to } \\
\text { health care and the } \\
\text { endorsement of principles } \\
\text { derived from human rights and } \\
\text { the best interests of child } \\
\text { development. }\end{array}$ \\
\hline
\end{tabular}


healthcare providers work together to provide MCHC services (Stevens, Lee, Sawada, 2000). Cooperation between health providers and health volunteers from immigrants produces coordinated community health teams and established good health centers; homebased workers with multilingual or bicultural abilities are able to provide emotional support, client advocacy, and health education on child development for low-income immigrant families and high-risk health problems. Language barrier and culture shock situations have an impact on immigrants regarding their adaptation to healthcare systems in new and unfamiliar environments (Ruiz-Casares et al., 2013). Therefore, comprehensive immigrant health promotion and healthcare services that focus on MCHC should be designed which use a combined healthcare system framework in conjunction with healthcare providers, families, and communities, based on immigrants' social and cultural contexts, so as to facilitate adaptation to the unfamiliar system of healthcare services in their new places of residence.

Furthermore, there are several literatures addressing MCHC services by PHN on some local sources, although they are not publicly documented or published.

\section{Implications for nursing services}

Furthermore, this literature review has implications for the improvement of the provision of $\mathrm{MCHC}$ by PHNs in immigrant populations. MCHC services should be designed with a multi-sector and multiprogram approach that involves the immigrant population, and healthcare providers. Provision should be made for immigration as part of the healthcare system. The improvement of bilingual or bicultural PHN competency could reduce the barriers to or limitations of immigrants in accessing healthcare services in communities. Furthermore, participatory action research that involves PHNs and immigrant populations in interactions to develop a MCHC services program should be examined to evaluate a comprehensive program for immigrants.

\section{Conclusions}

Immigrants have limited access to public healthcare services (PHC). PHNs deliver healthcare services through community and/or home-based service programs. The work of immigrant health volunteers is facilitated by a partnership between PHNs and the immigrant population in providing a comprehensive MCHC service to communities. There are barriers that currently impact on the development of PHN services of MCHC for immigrants. Strategies that can be implemented to improve PHN competencies in MCHC for immigrants include training in bicultural or bilingual and cultural competencies in visit programs. Furthermore, regulation of PHCs for immigrants should be reorganized to match global health standards relating to the universal human right to healthcare.

\section{Ethical aspects and conflict of interest}

The author declare that he has no conflict of interest.

\section{Acknowledgments}

The author would like to thank the Faculty of Nursing, University of Jember, as the research department of the author.

\section{References}

Calain-Watanabe T, Lee S. Access to maternal and child care for undocumented migrants in Japan. Journal of International Health. 2012;27(3):207-212.

Frisbie WP, Cho Y, Hummer RA. Immigration and the health of Asian and Pacific Islander adults in the United States. American Journal of Epidemiology. 2001;153(4):372-380.

Gany F, Thiel de Bocanegra H. Maternal-child immigrant health training: Changing knowledge and attitudes to improv health care delivery. Patient Education and Counseling. 1996;27(1):23-31.

Gu YH, Lee S, Ushijima H. A study on the needs of medical, maternal and child health care in Chinese women students at the University of Tokyo. The Tohoku Journal of Experimental Medicine. 2004;204(1):71-78.

Guendelman S, Angulo V, Wier M, Oman D. Overcoming the odds: access to care for immigrant children in working poor families in California. Maternal and Child Health Journal. 2005;9(4):351-362.

Jack SM, DiCenso A, Lohfeld L. A theory of maternal engagement with public health nurses and family visitors. Journal of Advanced Nursing. 2005;49(2):182-190.

Kim MJ, Cho HI, Cheon-Klessig YS, Gerace LM, Camilleri DD. Primary health care for Korean immigrants: sustaining a culturally sensitive model. Public Health Nursing. 2002;19(3):191-200.

$\mathrm{Ku} \mathrm{L}$. Improving health insurance and access to care for children in immigrant families. Ambulatory Pediatrics: The Official Journal of the Ambulatory Pediatric Association. 2007;7(6):412-420.

Paris R, Bronson M. A home-based intervention for immigrant and refugee trauma survivors: paraprofessionals working with high-risk mothers and infants. Zero to Three. 2006;27(2):37-45.

Polit DF, Beck CT. Essentials of nursing research: appraising evidence for nursing practice. 7th ed. Philadelphia: Wolters Kluwer Health. Lippincott Williams \& Wilkins; 2010.

Ruiz-Casares M, Rousseau C, Laurin-Lamothe A, Rummens JA, Zelkowitz P, Crépeau F, Steinmetz N. Access to health care for undocumented migrant children and pregnant women: the paradox between values and attitudes of health care professionals. Maternal and Child Health Journal. 2013;17(2):292-298. 
Stevens CS, Lee S, Sawada T. Undocumented migrant maternal and child health care in Yokohama. Japanese Studies. 2000;20(1):49-65.

Tveiten S, Severinsson E. Client supervision: meaning and experiences from the perspective of Norwegian public health nurses. Nursing and Health Sciences. 2004;6(4):279-286.

United Nations. International migration and development report of the Secretary-General (Vol. 56609). Geneva. 2014a

[cited 2017 Apr 14]. Available from:

http://www.un.org/en/development/desa/population/publicatio ns/pdf/migration/A-69-207_en.pdf

United Nations. Promotion and protection of human rights, including ways and means to promote the human rights of migrants (Vol. 58884). Geneva. 2014b [cited 2017 Mar 15]. Available from: https://reliefweb.int/report/world/promotionand-protection-human-rights-including-ways-and-meanspromote-human-rights 